\title{
THE LATENT EFFECT OF CHROMAFENOZIDE ON THE REPRODUCTIVE AND SOME BIOLOGICAL ASPECTS OF CHRYSOPERLA CARNEA (STEPHENS) (NEUROPTERA: CHRYSOPIDAE)
}

\author{
MERVAT A. KANDIL; HEMAT Z. MOUSTAFA and K. A. HASSAN \\ Plant Protection Research Institute, Dokki, Giza, Egypt \\ Author for corresponding: Dr.Mervatkandel@yahoo.com; hemat.zakaria@gmail.com
}

(Manuscript received 8 April 2018)

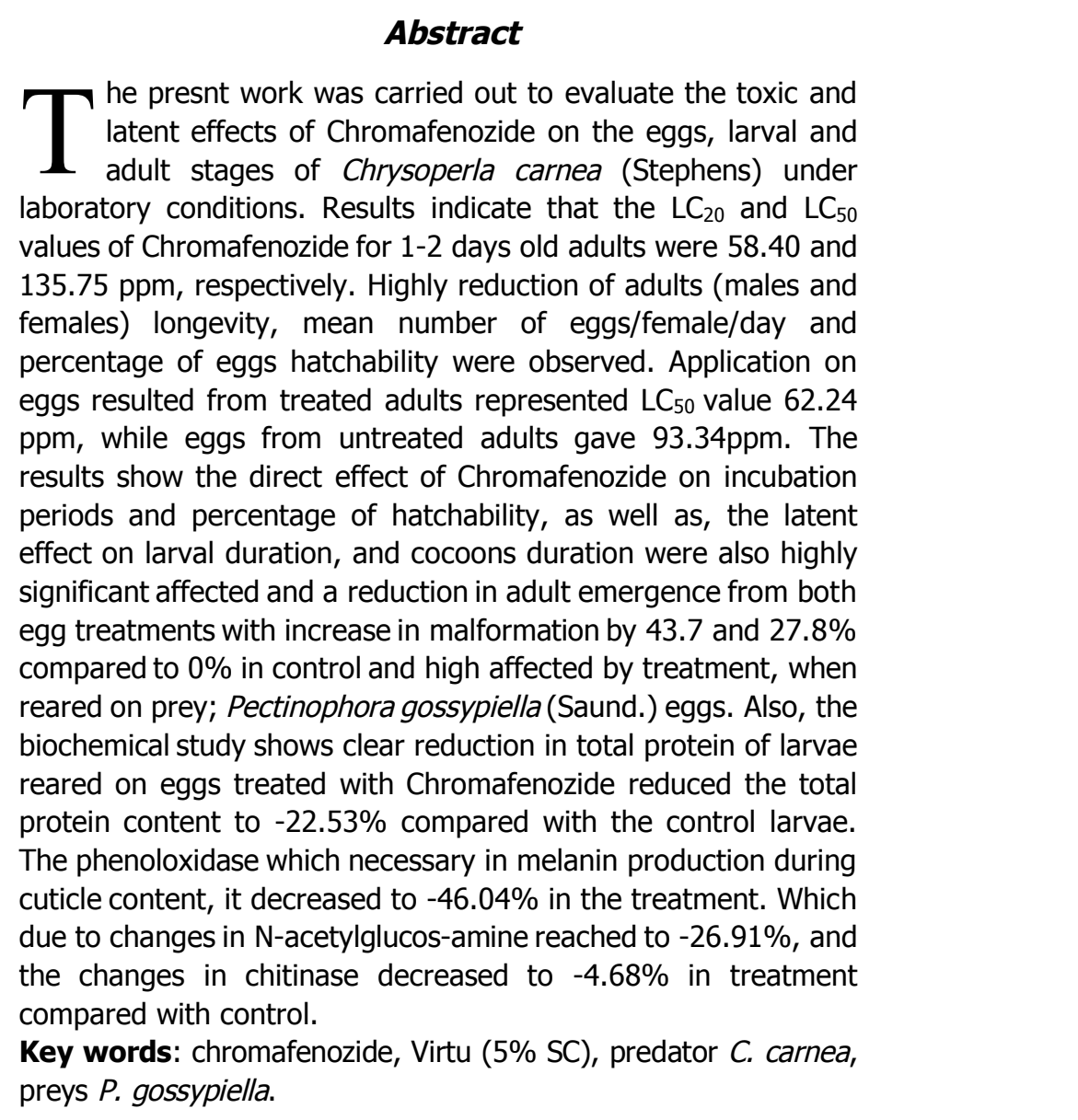

\section{INTRODUCTION}

Family Chrysopidae insects are predators of many species of arthropods, and play an important role in the natural biological control of several crop pests. Chrysoperla carnea (Stephens) (green lacewing) is an important natural enemy, (Chrysopidae: Neuroptera) (Tauber et al., 2000). This predator has been observed associated with a wide prey range including aphid nymphs, eggs and neonate larvae of Lepidopteran insects such as, Pectinophora gossypiella, Earias insulana (Boisd.) and Spodoptera littoralis (Boisd.), scale insects, whiteflies, mites and other soft bodied insects. 
Biological control agents such as predators are usually more sensitive to pesticides than the target pests. The adverse impact of insecticides on predators can be decreased /controlled through timing of insecticide application, choice of insecticide and dosage (Galven et al. 2005). Selective insecticides can minimize the likelihood of development of resistance in pest (Hassan et al. 1985). The use of selective chemicals is an important strategy within pest management programs, since it reduces the population of the phytophagous insects without significantly affecting the natural enemies.

Using pesticides for controlling insect pests resulted in many of side effects such as; pollution in air, water and soil, increase pesticide residues in agriculture crops and their products to residue toxicity on crops, in addition, pest resistance to various classes of pesticides. The excessive use of pesticides, particularly those with long residual effect, has caused several harms to natural balance between pests and their natural enemies (Amr and Marei, 2001).

Insect growth regulators fall into three categories based on mode of action: 1) juvenile hormone mimics, or analogs, (agonists); 2) ecdysone antagonists; and 3) chitin synthesis inhibitors. Juvenile hormone analogs arrest development and cause insects to remain in an immature stage, preventing them from completing their life cycle. Ecdysone antagonists disrupt molting by inhibiting metabolism of the molting hormone, ecdysone. Chitin synthesis inhibitors interfere with enzymes that stimulate the synthesis and formation of chitin, which is an essential component of the exoskeleton. Without chitin, insect pests die in the immature stage or mature into sterile male or female adults, as well as, produce maleformation in adult stages.

Chitinases are glycosyl hydrolases have the ability to degrade chitin directly to low molecular weight chitooligomers, which serve a broad range of industrial, agricultural (Yuli et al. 2004). Chitinases have been receiving an increased attention due to their role in the biocontrol of harmful insects (Mendonsa et al. 1996). NAcetylglucosamine is the monomeric unit of the polymer chitin, which forms the outer coverings of insects. Phenoloxidase is an important enzyme in the immune system that is effective in the melanin pathway (Soderhall and Cerenius, 1998) and plays a key role in melanin production during cuticle sclerotization at external wound sites and during defense responses, i.e., nodulation (Mason, 1955; Ratcliffe et al., 1984 and Cerenius et al., 2008).

The present investigation was carried out to study the toxicity and latent effect of Chromafenozide compound on the different stages of the Chrysoperla carnea. 


\section{MATERIALS AND METHODS}

\section{- Insects used as predator:}

\section{- Chrysoperla carnea:}

The adults of $C$. carnea used in this experiment were reared in Trichogramma mass production unit, Plant Protection Research Institute, Agriculture Research Center, Dokki, Giza, Egypt, and reared for one generation at bollworms department, Plant Protection Research Institute on P. gossypiella eggs and larvae for using in the experiment.

\section{- Insects used as prey:}

-Pectinophora gossypiella:

The eggs of PBW used in these experiments were reared in the laboratory on semi-artificial diet according to Rashad and Ammer (1985).

\section{-Insecticides used: IGR}

- Common name: chromafenozide is a novel dibenzoylhydrazine and is categorized to be an insect hormone ecdysone moulting hormone agonists.

Trade name: Virtu ( $5 \% \mathrm{SC}$ ), and used at the rate of $40 \mathrm{~cm}^{3} / F e d a n$.

\section{-Toxicological studies:}

To study the activity of Chromafenozide, against newly emergence adults of C. Carnea, serial concentrations ranged from 200, 100, 50, 25 and $21.5 \mathrm{ppm}$ of for Chromafenozide were freshly prepared from the stock solution of the commercial compound ( $1 \mathrm{gm} / 1$ liter water). The $\mathrm{LC}_{20}$ and LC 50 were estimated by Finney (1971).

\section{-Treatment of $C$. carnea adult:}

Ninety pairs of $C$. carnea from the stock culture were collected and divided to three groups each group 30 pairs of male and female adults. Each group divided to 10 pairs of $C$. carnea adult was used in three replicates in glass cages under the previously mentioned rearing condition. The first group, fed on piece of cotton wool previously soaked only on $\mathrm{LC}_{20}(58.40 \mathrm{ppm})$, and the second group fed only on LC 50 (135.73ppm) of chromafenozide, for adults feeding and changed after 2 days, by a piece of cotton wool soaked in the semi arteficial diet containing (2 yeast extract: 1 fructose: 1 distilled water) provided once a day on sticky tape with help of fine brush Hassan (2014). While, the last group fed on the original diet only as control. Each cage was examined daily where the pre-oviposition, oviposition, post-oviposition periods and number of egg laid/ female and longevity of males and females for compound were recorded. 


\section{-Treatment of $C$. carnea eggs:}

The eggs resulted from untreated and treated adults with $\mathrm{LC}_{50}$; sequence treated by the same concentrations $(400,200,100,50$ and $25 \mathrm{ppm})$ of Chromafonozide.

The strips of muslin cloths with attached eggs of $C$. carnea were dipped into the aforementioned selected concentrations of chromafenozide. The control eggs were dipped into water only. The strips were left for 1-2 hr until drying, kept at the rearing condition and examined daily until eggs hatched. $\mathrm{LC}_{20}, \mathrm{LC}_{50}$ and $\mathrm{LC}_{90}$ were determined and recorded.

\section{-Latent effect of chromafenozide on C. carnea:}

Newly hatched larvae of $C$. carnea resulted from eggs treated with the dose of $\mathrm{LC}_{20}$ and $\mathrm{LC}_{50}$ of chromafenozide were kept, individually, in glass vials stoppered with cotton-wool and fed on eggs of PBW. The vials were examined daily until the cocoons were formed. Larval and cocoon durations, percentage of adult emergence and malformed were estimated. All studies were carried out at $26 \pm 1{ }^{\circ} \mathrm{C}$ and $65-70 \% \mathrm{R}$. $\mathrm{H}$.

\section{-Effect of recommended and LC $_{50}$ treatment on $C$. carnea larvae:}

Under the same laboratory conditions, newly hatched larvae resulted from untreated eggs of $C$. carnea were kept individually in glass vials Stoppard with cottonwool and fed on eggs of PBW treated with Recommended and LC 50 $_{50}$ dose of chromafenozide. The vials were examined daily until the cocoons were formed, larval and cocoon durations and malformed for each group were estimated. As well as percentage of adult emergence and malformed were also estimated.

The recorded data values were statistically analyzed with one-way analysis of variance (ANOVA) $(P<0.05 \%)$ (Snedecor, 1952) and Duncan's multiple range test of means (Duncan, 1955) were used.

\section{-Biochemical studies:}

\section{-Determination of enzyme activity:}

Determination of chitinase activity was prepared according to Bade and Stinson (1981) and the reaction mixture of enzyme assay according to Ishaaya and Casido (1974). Determination of $\mathrm{N}$-acetyl- glucosamine by the sensitive method of Waterhouse et al. (1961). Phenoloxidase activity was determined according to modification of Ishaaya (1971) and Total proteins were determined by the method of Bradford (1976).

\section{-Statistical analysis:}

One way analysis of variance (ANOVA) and Duncan's multiple range tests of means were used Duncan's, (1955). 


\section{RESULTS AND DISCUSSIONS}

\section{Effect of Chromafenozide on reproductive, fecundity and longevity of treated Chrysoperla carnea adults:}

Treated adults of $C$. carnea with $\mathrm{LC}_{20}$ and $\mathrm{LC}_{50}$ values of Chromafenozide were 58.40 and 135.75 ppm, respectively, (Table 1 ).

\section{Ovipositonal period:}

Table (1) showed that the ovipostion period of $C$. carnea females treated with $\mathrm{LC}_{20}(58.40 \mathrm{ppm})$ and $\mathrm{LC}_{50}(135.75 \mathrm{ppm})$ were slightly shorter than those untreated. These periods were 12.86 and 10.3 days/ female, respectively, compared with 16.6 days in untreated.

\section{Female fecundity:}

The average number of eggs laid/ female and percentage of hatchability decreased when the predator females fed on chromafenozide compared to untreated one. The mean numbers of deposited eggs were 121.0 and 80.6 eggs/female when treated with $\mathrm{LC}_{20}$ and $\mathrm{LC}_{50}$, respectively, compared to 168.3 eggs/female in untreated. On the other hand, the hatchability was significantly high decrease up to $53 \%$ when female treated with $\mathrm{LC}_{50}$ and $68 \%$ with $\mathrm{LC}_{20}$, Table (1). From this data it can be concluded that; when this compound was applied to both sexes (females \& males) of insect predator, BPUs induced a variety of effects on reproduction; it caused a decrease in fecundity, fertility and/or hatchability to half time than contol.

Theses resulted agreed with (Apperson et al., 1978; Medina et al., 2002 and 2003a). They recorded that used (IGR) diflubenzuron caused decrease in total eggs laid and hatchability in the lacewing $C$. carnea and in the larvae survival. Medina et al., (2003b) recorded that the three modern insecticides, pyriproxfen, spinosad and tebufenozid have highly effect on reproduction of $C$. carnea.

Table 1. Reproductive, fecundity and longevity of treated Chrysoperla carnea adults with chromafenozide

\begin{tabular}{|c|c|c|c|c|c|c|c|c|c|c|}
\hline \multirow[b]{2}{*}{ Treatment } & \multirow{2}{*}{$\begin{array}{l}\text { Conc. } \\
\text { Ppm }\end{array}$} & \multirow{2}{*}{$\begin{array}{c}\text { Pre- } \\
\text { ovipostion }\end{array}$} & \multirow{2}{*}{$\begin{array}{c}\text { Ovipostio } \\
n \\
\text { period }\end{array}$} & \multirow{2}{*}{$\begin{array}{c}\text { Post- } \\
\text { ovipostion }\end{array}$} & \multirow{2}{*}{$\begin{array}{l}\text { Total no. of } \\
\text { eggs/q/day }\end{array}$} & \multirow{2}{*}{$\begin{array}{c}\text { Mean no. of } \\
\text { eggs/f/ } \\
\text { Day }\end{array}$} & \multirow{2}{*}{$\begin{array}{l}\text { 翕 } \\
\text { 产 } \\
\text { 言 }\end{array}$} & \multirow{2}{*}{ 望 } & \multicolumn{2}{|c|}{ Adult longevity } \\
\hline & & & & & & & & & $q \uparrow$ & $0^{\circ} 0^{\circ}$ \\
\hline Check & $\cdots$ & $2.3^{\mathrm{a}} \pm 0.2$ & $16.6^{a} \pm 0.9$ & $2.9^{a} \pm 0.3$ & $168.3^{a} \pm 8.6$ & $10.7^{\mathrm{a}}$ & $82^{\mathrm{a}}$ & - & $21.8^{a} \pm 1.6$ & $16.9^{\mathrm{a}}$ \\
\hline $\mathrm{LC}_{20}$ & 58.40 & $4.2^{b} \pm 1.1$ & $12.86^{b} \pm 1.3$ & $3.3^{a} \pm 0.6$ & $121.0^{6} \pm 3.3$ & $10.6^{\mathrm{a}}$ & $68^{b}$ & 44.97 & $20.6^{\mathrm{ab}} \pm 3.2$ & $14.3^{b}$ \\
\hline$L C_{50}$ & 135.75 & $3.5^{a} \pm 1.2$ & $10.3^{c} \pm 1.6$ & $3.0^{a} \pm 0.1$ & $80.6^{c} \pm 9.8$ & $6.9^{b}$ & $53^{c}$ & 71.37 & $16.8^{b} \pm 2.1$ & $10.16^{\mathrm{C}}$ \\
\hline LSD & & 1.52 & 1.52 & 0.69 & 26.36 & 3.42 & 5.37 & & 2.379 & 1.65 \\
\hline
\end{tabular}

\section{-Effect of chromafenozide on $\boldsymbol{C}$. carnea adult longevity}

The predator female and male longevities were slightly shortened when the adult treated by $\mathrm{LC}_{50}$ data in Table (1) which recorded the differences between control 
and treated adults longevity period. These periods were 14.3 and 10.16 days/ male and 20.6 and 16.8 days/ female treated with $\mathrm{LC}_{20}$ and $\mathrm{LC}_{50}$, respectively, compared with $16.9 \& 21.8$ days in untreated male and female.

\section{-Effect of chromafenozide on eggs stage}

Data in Table (2), show that the eggs incubation period and different immature stages of $C$. carnea when sequence treated eggs resulted from females treated with $\mathrm{LC}_{50}$ values (62.24) (E1) and eggs resulted from untreated females and sequence treated by LC $\mathrm{C}_{50}$ (92.34) of chromafenozide (E2) compared with untreated eggs (check eggs).

Data in Table (2) recorded that the egg resulted from female treated with chromafenozide and sequence treated (E1) the more affected and susceptibility to chromafenozide ( $\mathrm{LC}_{50}$ value estimated by $62.24 \mathrm{ppm}$, on contrast this value increased to $92.34 \mathrm{ppm}$ when treated eggs resulted from untreated females (E2).

\section{-Egg stage:}

Data in Table (2) indicated that incubation period affected by repeated the treatment with $\mathrm{LC}_{50}$ of chromafenozide; this average increased significantly to 6.3 days/ eggs (E1) after treated with the $\mathrm{LC}_{50}$ and 5.4 days in (E2) compared to 3.4 days in untreated eggs.

Table 2. Immature stages resulted from treated eggs

\begin{tabular}{|c|c|c|c|c|c|c|c|c|c|c|}
\hline \multirow[b]{2}{*}{ Treatment } & \multirow[b]{2}{*}{$\begin{array}{l}\text { Conc. } \\
\text { Ppm }\end{array}$} & \multirow[b]{2}{*}{$\begin{array}{l}\text { Incubation } \\
\text { period in } \\
\text { days }\end{array}$} & \multirow[b]{2}{*}{$\begin{array}{l}\text { 폴 } \\
\text { 獄 } \\
\text { 产 }\end{array}$} & \multirow[b]{2}{*}{$\begin{array}{l}\text { Larvae } \\
\text { duration in } \\
\text { days } 1^{\text {st }} 3^{\text {rd }} \\
\text { instar }\end{array}$} & \multicolumn{3}{|c|}{$\%$ Cocoon stage } & \multirow[b]{2}{*}{ 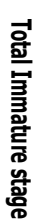 } & \multirow[b]{2}{*}{ 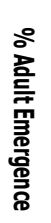 } & \multirow[b]{2}{*}{ 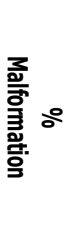 } \\
\hline & & & & & $\begin{array}{c}\% \\
\text { Pupation } \\
\text { for larvae }\end{array}$ & $\begin{array}{l}\text { Duration in } \\
\text { days }\end{array}$ & $\begin{array}{c}\text { Malfor } \\
\text { mation } \\
\%\end{array}$ & & & \\
\hline Eggs(1) & 62.24 & 6.3 & 84 & $18.3^{6} \pm 2.1$ & 75 & $9.8^{b} \pm 0.9$ & 10 & 28.1 & 57 & 43.7 \\
\hline Eggs(2) & 92.34 & $5.4 \pm 0.3$ & 51 & $16.4^{c} \pm 1.9$ & 81 & $8.2^{6} \pm 0.4$ & 6 & 24.6 & 63 & 27.8 \\
\hline $\begin{array}{l}\text { Eggs(3) } \\
\text { check }\end{array}$ & - & $3.4 \pm 0.2$ & 98 & $10.3 \pm 1.2$ & 96 & $6.3^{\mathrm{a}} \pm 2.1$ & $\cdots$ & 16.6 & 98 & 0.0 \\
\hline
\end{tabular}

1- Eggs resulted from females treated by $L C_{50}$ values (62.24) and sequence treated by $\mathrm{LC}_{50}$ of chromafenozide (E1)

2- Eggs resulted from untreated females and sequence treated by $\mathrm{LC}_{50}(92.34)$ of chromafenozide (E2)

3- Untreated eggs

-Durations of immature stages of $C$. carnea resulted from (E1\&E2) treated with LC $_{50}$ of chromafenozide:

\section{-Larval stage:}

Table (2) demonstrates that the average larval duration resulted from treated or sequence treated eggs with $\mathrm{LC}_{50}$ varied from $1^{\text {st }}$ instar to $3^{\text {rd }}$ instar larvae when fed on P. gossypiella eggs. 
The larval duration period significantly increased in case of treated eggs compared to untreated eggs, Table (2). The duration of larval stage averaged 18.3 days when larvae hatched from eggs treated by $\mathrm{LC}_{50}$ (62.34) of chromafenozide (E1) and 16.4 days when larvae resulted from (E2) treated eggs by $\mathrm{LC}_{50}(92.24)$ and reared on P. gossypiella, compared to 10.3 days/larvae resulted from eggs check.

These data indicate that the eggs treated with $\mathrm{LC}_{50}$ prolonged the duration of larval instars approximately from 1.6 to 1.8 times than control.

\section{Cocoon:}

The duration of cocoon increased when resulted from (E1) or (E2) than control, Table (2) showed that, pupal duration were 9.8 and 8.2 days resulted from treated eggs (E1 \& E2) respectively, compared with 6.3 days for untreated eggs with larvae fed on PBW. The total immature stage, from $1^{\text {st }}$ instar larvae to adults emergence were 28.1 days in (E1) and 24.6 days in (E2) compared to 16.6 days in control.

In this respect, Vinuela et al. (2001) found that 13 different pesticides induced only slight reduction in percent of egg-hatch in $C$. carnea. Shaalan and Kandil (2010) observed that Radiant $12 \%$ shortened the life span and a reduction in fecundity of predatory C. carnea. In contrast, Dutton et al. (2003) also found that developmental period of $C$. carnea lasted longer when larvae were fed upon Btcontaminated S. littoralis larvae. Ali et al. (2015) found that Neem and Datura was less toxic than confidor against first, second, and third instar larvae of $C$. carnea as well as pupae and adults are also affected by confider. Zia et al. (2017) spinosad and flubendiamide are relatively safe. Imidachloprid was safest for the adults causing 10 to $40 \%$ mortality. Chloropyrifos is the most injurious insecticide used causing highest mortality $33-100 \%$ of C. carnea larvae and adults. Also, Bhojani et al., (2018) assessed the relative toxicity against the green lacewing, Chrysoperla zastrowi sillemi in the laboratory. buprofezin $25 \mathrm{SC}$ at $0.05 \%$ and fipronil $5 \mathrm{SC}$ at $0.02 \%$ were categorized as slightly harmful. While assessing relative toxicity through food contamination technique against the adults of $C$. zastrowi, buprofezin 25 SC at $0.05 \%$ was categorized as harmless.

\section{Percentage of Adult emergence:}

Data in Table (2) show the percentages of adult emergence from the pupae resulted from treated eggs (E1\&E2) when reared on PBW eggs decrease to 57 and 63 $\%$ compared to $98 \%$ in the control. Generally, treating (1-2 day old) eggs of $C$. carnea with $\mathrm{LC}_{50}$ compound related to chitin synthesis inhibitor and /or moulting hormone agonists reflected high effects on immature stage and the adult stage and reduced fecundity and hatchability in comparison with control. 
(STEPHENS) (NEUROPTERA: CHRYSOPIDAE)

\section{Percentages of larvae and cocoons malformed:}

Data in Table (2) and (Fig. 1, 2\&3) show the late effect of chromafenozide on larvae, cocoons and adults malformed percentages when resulted from eggs treated with $\mathrm{LC}_{50}$. The percentages increased with the treated eggs resulted from adult treated to $43.7 \%$ and decreased approximately to half time $27.8 \%$ when treated eggs resulted from adult untreated compared with $0 \%$ in control.
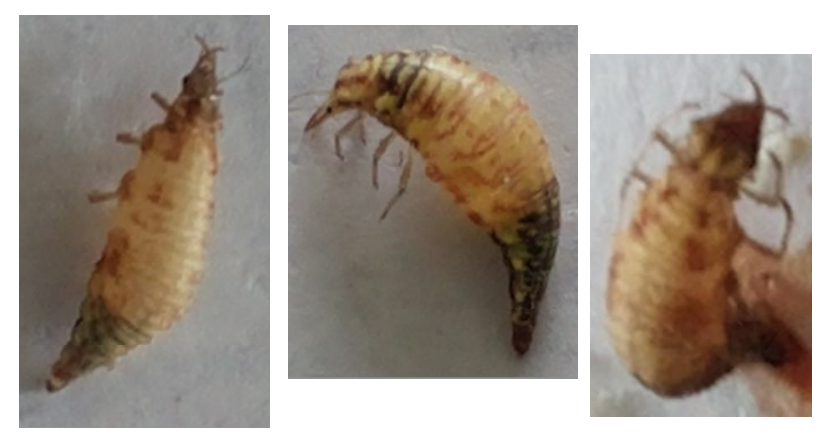

Fig. 1. Effect of $\mathrm{LC}_{50}$ on $3^{\text {rd }}$ instar larvae of $C$. carnea

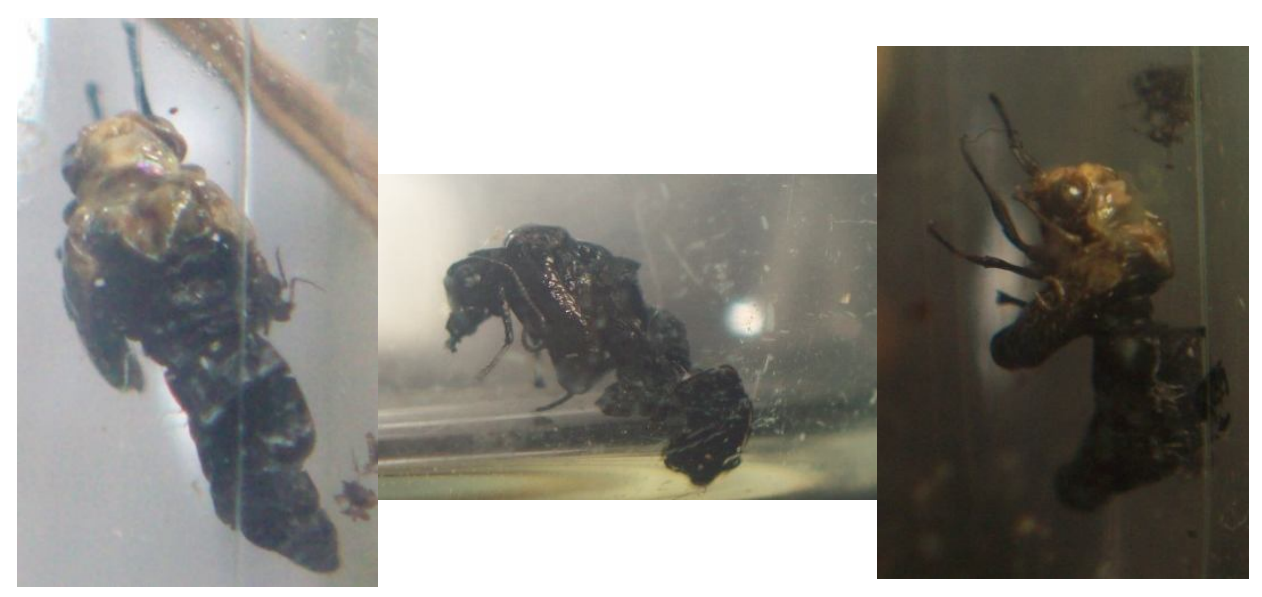

Fig. 2. malformed adults resulted from eggs resulted from adult treated and sequence treated by $\mathrm{LC}_{50}$ of chromofenozide with $\mathrm{LC}_{50}(62.24 \mathrm{ppm})$. 


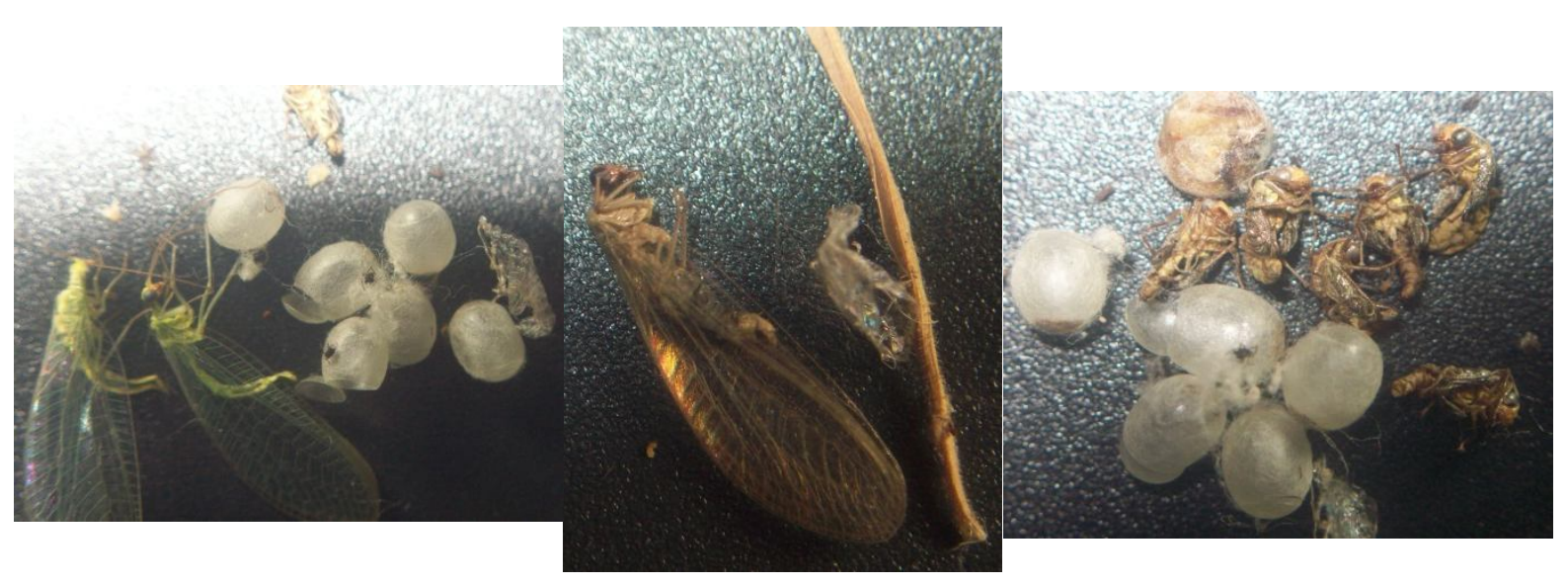

Fig. 3. Malformed adults resulted from eggs treated with $\mathrm{LC}_{50}(92.34 \mathrm{ppm})$

\section{Duration and feeding capacity of $\boldsymbol{C}$. carnea when fed on P. gossypiella eggs treated with recommend and half recommend compound of chromafenozid:}

Data in Table (3) demonstrates that the average larval duration from $1^{\text {st }}$ to $3^{\text {rd }}$ instar larvae increased significantly when fed on treated $P$. gossypiella eggs with recommended and half recommended concentrations of chromafenozide compared with untreated eggs. The duration of larval instar averaged 21.6 and 19.3 days when larvae fed on $P$. gossypiella eggs treated with recommended and half recommended concentrations of chromafenozide, respectively, compared to 10.7 days/larvae in control. These data indicate that feeding $C$. carnea on eggs treated with recommend and half recommend prolonged in the duration of larval instar approximately 2 time than control at the same time, decreased the feeding capacity to 223 and 254 treated eggs/ larvae of $C$. carnea, respectively, compared to 385 eggs in control. Medina et. al. (2003b) recorded the effect of three modern insecticides, pyriproxfen, spinosad and tebufenozid on toxicity, hatchability eggs and survival of Chrysoperla carnea.

\section{Malformation larvae:}

As shown in Table (3) and Fig. (3), malformed percentage appeared in larvae resulted when fed on treated eggs with recommend and half recommended concentrations, the high percent estimated by $35 \%$ when larvae fed on treated eggs with recommended chromafenozid and the lowest percentage of malformation recorded by $21.3 \%$ when larvae feed on treated eggs with half recomnended. Generally, chromafenozid treatments caused very small larvae and dark larvae in thorax and late abdomen and darken larvae after mortality. 
Table 3. Duration and feeding capacity of $C$. carnea when fed on $P$. gossypiella treated with chromafenozide

\begin{tabular}{|c|c|c|c|c|c|c|c|c|c|}
\hline \multirow[b]{2}{*}{$\begin{array}{c}\text { Tested } \\
\text { Compound }\end{array}$} & \multirow[b]{2}{*}{$\begin{array}{c}\text { Treated } \\
\text { PBW } \\
\text { Eggs }\end{array}$} & \multirow[b]{2}{*}{$\begin{array}{c}\text { Initial } \\
\text { number }\end{array}$} & \multirow{2}{*}{$\begin{array}{c}\% \\
\text { Mortality } \\
\text { In 1-3 } \\
\text { instar } \\
\text { larvae }\end{array}$} & \multicolumn{3}{|c|}{ Larval stage } & \multicolumn{2}{|c|}{ Pupal stage } & \multirow[b]{2}{*}{$\begin{array}{c}\text { Total } \\
\text { immature } \\
\text { stage }\end{array}$} \\
\hline & & & & $\begin{array}{l}\text { Duration } \\
\text { from 1-3 } \\
\text { instar } \\
\text { larvae }\end{array}$ & $\begin{array}{l}\text { Feeding } \\
\text { capacity }\end{array}$ & $\begin{array}{c}\% \\
\text { Malformed }\end{array}$ & Duration & $\begin{array}{c}\% \\
\text { Mortality } \\
\text { \& dead }\end{array}$ & \\
\hline \multirow{4}{*}{ chromafenozide } & Recommended & 75 & $58^{\mathrm{a}}$ & $21.6^{\mathrm{a}}$ & 223 & $35.0^{\mathrm{a}}$ & $13.8^{\mathrm{a}}$ & 16.3 & $35.4^{\mathrm{a}}$ \\
\hline & $\begin{array}{l}\text { Half- } \\
\text { recommend }\end{array}$ & 75 & $35.3^{b}$ & $19.3^{b}$ & 254 & $21.3^{b}$ & $9.5^{b}$ & 12.3 & $28.8^{\mathrm{b}}$ \\
\hline & Control & 30 & $2^{c}$ & $10.7^{c}$ & 385 & - & $6.8^{c}$ & 1.3 & $17.5^{c}$ \\
\hline & LSD & & 2.40 & 1.41 & & 2.66 & 1.67 & & 1.95 \\
\hline
\end{tabular}

Malformed $C$. Carnea larvae after feeding on $P$. gossypiella eggs treated with recommend of chromafenozide treated.

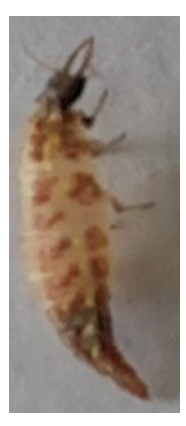

(1)

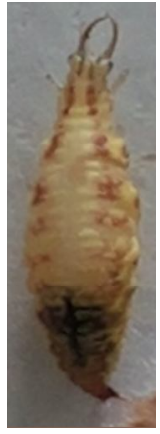

(2)

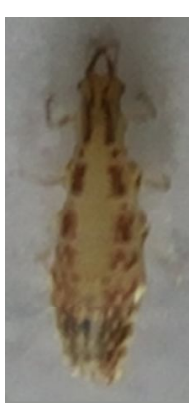

(3)
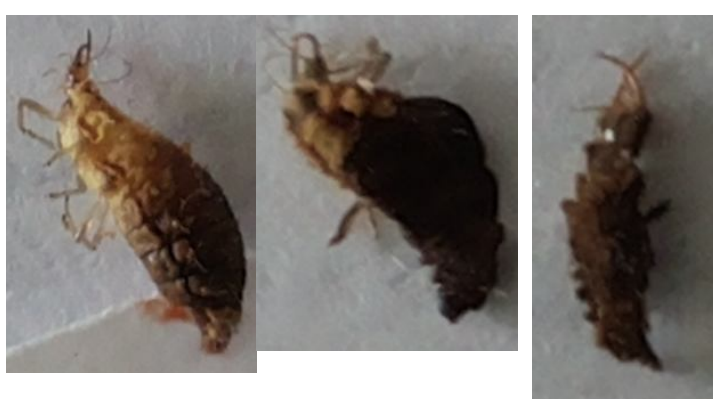

(4)

Fig. 4. Effect of recommend IGR on $2^{\text {nd }}$ instar larvae of $C$. carnea

1-2-3-Disappeared of the melanin content from cuticle larvae with a small larvae

\section{$1,2,3$ and 4- Dark larvae in late abdomen}

\section{Cocoon stage:}

Data recorded in Table (3) and Fig. (4) show that duration of cocoon increased significantly when larvae feed on eggs treated with recommend and half recommended compound it lasted 13.8 days and 9.5 days, respectively, compared to 6.8 days when fed on untreated eggs of PBW, The total immature stage, from $1^{\text {st }}$ instar larvae until emergence of adults were 35.4 and 28.8 days when fed on PBW eggs treated with two concentration, respectively, compared to 17.5 days in control.

\section{-Biochemical studies:}

Some important enzymes such as total protein, phenoloxidase, chitinase and $\mathrm{N}$-acetylglucoseamine which plays a key role in development and molting processes in body of $C$. carnea;. Recorded in Table (4) showed the effect of Chromafenozide on some biochemical analyzes of $C$. carnea, it cussed changes in the total contents of protein and phenoloxidase when the $2^{\text {nd }}$ instar larvae fed on treated eggs of PBW with 
recommended concentration of Chromafenozide. Treatment with Chromafenozide reduced the total protein content to $-22.53 \%$ compared with the control larvae. While the phenoloxidase which very necessary in melanin content during cuticle production high decreased to $-46.04 \%$ in the treatment Fig 4 (1, 2 \&3). Assar et al (2012) found that after treated $S$. littoralis with the IGR, the activity of phenoloxidas decreased significantly. Sabry and Khedr (2014) found that molting hormone agonist decreased phenoloxidase activity comparing to control larvae of $S$. littoralis as follows: methoxyfenozide (-20.91\%) and tebufenozide (-3.84\%).

Table 4. Effect of Chromafenozide on some biochemical analyzed of $C$. carnea.

\begin{tabular}{|c|c|c|c|}
\hline Treatment & Treted & Control & $\begin{array}{c}\% \\
\text { Changes }\end{array}$ \\
\hline $\begin{array}{l}\text { Total protein } \\
\text { (mg/g.b.wt) }\end{array}$ & $14.10^{\mathrm{b}} \pm 0.38$ & $18.20^{\mathrm{a}} \pm 0.53$ & -22.53 \\
\hline $\begin{array}{c}\text { Phenoloxidase } \\
\text { (O.D. unit } \times 10^{3} / \mathrm{min} / \text { g.b.wt) }\end{array}$ & $2745.89^{b} \pm 53.31$ & $5088.89^{\mathrm{a}} \pm 66.93$ & -46.04 \\
\hline $\begin{array}{c}\text { Chitinase } \\
(\mu \mathrm{g} N A G A / m i n / g . b . w t)\end{array}$ & $1211.00^{\mathrm{a}} \pm 12.43$ & $1271.56^{a} \pm 24.49$ & -4.68 \\
\hline $\begin{array}{c}\mathbf{N} \text {-acetylglucosamine } \\
(\mu \mathrm{g} N A G A / g . b . w t)\end{array}$ & $476.00^{\mathrm{b}} \pm 7.21$ & $651.33^{\mathrm{a}} \pm 12.14$ & -26.91 \\
\hline
\end{tabular}

Data in Table (4) showed the changes in chitinase decreased to $-4.68 \%$ in treatment compared by control. Whereas, changes in $\mathrm{N}$-acetylglucosamine reached to $-26.91 \%$ compared with control. Theses data can be indicate that, when PBW eggs treated with Chromafenozide and directly fed the predator larvae on the treated PBW eggs, some malformed appeared on predator instars larvae, this may be due to molting hormone agonist decreased chitin's by $-4.68 \%$ and $\mathrm{N}$-acetylglucosamine to $26.91 \%$.

Sabry and Khedr (2014) showed reduction in chitinase activity $(-3.82 \%)$ when treated the $4^{\text {th }}$ instar larvae of $S$. littoralis.

\section{CONCLUSION}

In conclusion, we demonstrate in this study the direct and indirect effect of Chromafenozide on some biological and biochemical parameters of the predator $C$. carnea.

Acknowledgement: To Dr Ali -El said for statistical analyzed of all data. 


\section{REFERENCES}

1. -Ali, S. S. ; M.Y. Khaskheli; S. S. Ahmed; H. Rizwana; A. Bukero; G. Thebo; S.A. Nahyo; I.A. Rattar and S. Ahmad. 2015. Effects of Bio-Pesticides on Biology of Chrysoperla carnea F. (Neuroptera: Chrysopidae) Journal of Basic \& Applied Sciences, 11:559-566.

2. -Amr, E. M. and S.S. Marei. 2001. Effect of Nerium Oleander leaf extract on the green Lacewing Chrysoperla Carnae Steph. E gyption J. Biol. Pest Contraol. 11(1): 39-44.

3. -Apperson, C.S.; C.H. Schaefer; A.E. Colwell; G.H. Werner; N.L. Anderson; Jr. E.F. Dupras and D.R. Longanecker. 1978. Effects of diflubenzuron on Chaocorus astictopus and nontarget organisms and persistence of diflubenzorun in lentic habitats. J. Econ. Entomol. 71: 521-527.

4. -Assar, A.A.; M.M. Abo-El-Mahasen; N.M. Harba, and A. A. Rady. 2012. Biochemical Effects of Cyromazine on Culex Pipiens Larvae (Diptera: Culicidae). Journal of American Science 8(5):443-450.

5. -Bade, M. L. and A. Stinson. 1981. Biochemistry of insect differentiation. A system for studying the mechanism of chitinase activity in vitro. Archs Biochem. Biophyscs., 206:213-221.

6. -Bhojani, D.V.; H.R. Desai; C.U. Shinde and G.R. Bhanderi. 2018. Relative Toxicity of Commonly Used Insecticides and Combination Products in Cotton Ecosystem to Chrysoperla zastrowi sillemi (Esben-Peterson) under Laboratory Condition. Int.J.Curr.Microbiol.App.Sci. 7(1): 1523-1533.

7. -Bradford, M.M. I976. A rapid and sensitive method for the quantitation of microgram quantities of proteins utilizing the principle of protein-dye binding. Anal.Biochem. 72:248-254.

8. -Cerenius, L.; B.L. Lee and K. Soderhall. 2008. The proPO-system: pros and cons for its role in invertebrate immunity. Trends Immunol. 29: 263-271.

9. -Duncan, D.B. 1955. Multiple range and multiple F tests. Biometrics. 11:1-42.

10. -Dutton, A.; H. Klein; J. Romeis and F. Bigler. 2003. Prey-mediated effects of Bacillus thuringiensis spray on the predator Chrysoperla carnea in maize.Biol. Control 26:209-215.

11. -Finney, D. J. 1971. Probit Analysis, 3rd Ed Cambridge University Press, Cambridge. 333pp.

12. -Galven, T. I.; R. I. Koch and W.D. Hutchison. 2005. Toxicity of commonly used insecticides in sweet corn and soybean to multicolored Asian lady beetle (Coleoptera: Coccinelidae). J. Econ. Entomol. 98(3): 780-789. 
13. -Hassan, K. A. 2014. Feeding capacity and host preference of Chrysoperla carnea (Stephens) (Neuroptera: chrysopidae) on three different insect prey under laboratory conditions. J. Plant Prot. and Path., Mansoura Univ., 5 (12): 1045 1051.

14. -Hassan, S. A.; F. Klinghauf and F. Shanin. 1985. Role of Chrysoperla carnea as an aphid predator on sugar beet and the effect of pesticides. Zeitschrift fur angewandte entomologie. 100: 163-174.

15. -Ishaaya, I. and J. E. Casida. 1974. Dietary TH-6040 alters composition and enzyme activity of housefly larval cuticle, pestic. Biochem. Physiol. 4:484-490.

16. -Ishaaya, I. 1971. Observations on the phenoloxidase system in the armored scales Aonidiella aurantii and chrysomphalus aonidum. Comp. Biochem. Physiol. 39:935-943.

17. -Medina, P.; F. Budia; G. Smagghe and E. Vinuela. 2002. Activity of spinosad, diflubenzuron and azadirachtin on eggs and pupae of Chrysoperla carnea (Stephens) under laboratory conditions. Biocontrol Sci. Technol., 11:597-610.

18. -Medina, P.; F. Budia; L. Tirry and E. Vinuela (2003a). Toxicity and absorption of azadrachtin, diflubenzuron, pyriproxfen and tebufenozide after direct spray in predator larvae of Chrysoperla carnea (Stephens) (Neuroptera: Chrysopidae). Environ. Entomol. 32:196-203.

19. -Medina, P.; F. Budia; P. Del Estal and E. Vinuela (2003b). Effect of three modern insecticides, pyriproxfen, spinosad and tebufenozid on survival and reproduction of Chrysoperla carnea adults. Ann. Appl. Biol. 142:55-61.

20. -Mendonsa, E.S.; P.H. Vartak,; J.U. Rao and M.V. Deshpande. 1996. An enzyme from Myrothecium verrucaria that degrades insect cuticles for biocontrol of Aedes aegypti mosquito. Biotechnol Lett. 18:373-6.

21. -Mason, H.S. 1955. Comparative biochemistry of the phenolase complex. Adv. Enzymol. 16:105-184.

22. -Rashad, M.A. and E.D. Ammar. 1985. Mass rearing of the spiny bollworm, Earias insulana (Bosid) on semi artificial diet. Bull. Soc. Ent. Egypt. 65:239-44.

23. -Ratcliffe, N.A.; C. Leonard and A.F. Rowley. 1984. Prophenoloxidase activation: nonself recognition and cell cooperation in insect immunity. Sci. 226:557-559.

24. -Sabry, H. M. and M. A. Khedr. 2014. Biochemical and Histological Variations Induced by IGRs in Spodoptera littoralis (Boisd.) Glob. J. Environ. Sa. Toxicol. Vol. 1(2): PP. 163 178.

25. Shaalan, H.H. and Mervat, A. Kandil. 2010. Effect on radiant insecticide on the biology and hatchability of Chrysoperla carnea (stephens) (Neuroptera: Chrysopidae). Egypt. J. Agric. Res. 88(3):701-710. 
26. -Snedecor, G. W. 1952. Statistical methods $5^{\text {th }}$ Ed, Iowa State Col.N.Y.

27. -Soderhall, K. and L. Cerenius. 1998. Role of the prophenoloxidaseactivating system in invertebrate immunity. Curr. Opin. Immunol. 10: 8-23.

28. -Tauber M.J.; C.A. Tauber; K.M. Daane and K.S. Hagen. 2000. Commercialization of predators: recent lessons from green lacewings (Neuroptera: Chrysopidae). Am. Entomol. 46:26-38.

29. -Vinuela E.; M.P. Medina; M. Schneider; M. Gonzalez; F. Budia; A. Adan and P. Del Estal. 2001. Comparison of side- effects of spinosad, tebufenozide and azidirachtin on the predators Chrysoperla carnea and Podisus maculiventris and parasitoids Opius concolor and Hyposoter didymator under laboratory conditions. IOBC/WRPS Bull., 24:25-34.

30. -Waterhouse, D.F.; R. H. Hockman and J. W. Mckeller. 1961. An investigation of chitinase activity in cockroach and termite extracts. J. Insect Physiol. 6:96-112.

31. -Yuli, P.E.; M.T. Suhartono; Y. Rukayadi; J.K. Hwang and Y.R. Pyunb. 2004. Characteristics of thermostable chitinase enzymes from the Indonesian Bacillus sp.13.26. Enzyme Microb Technol. 35:147-53.

32. -Zia, U.; A. S. Muhammad; A. Saboor; B. Hazrat; H. Dilbar; K. M. Talha; M. Muhammad; A. Asad and I. A. Muhammad. 2017. In vitro study of comparative toxicity of different insecticides against Chrysoperla carnea (Stephens) (Neuroptera: Chrysopidae). J. Entomol. and Zool. Studies. 5(3): 697-702. 


\title{
التأثير المتاخر لمركب Chromafonozide علي إنتاجية وبعض الخصائص البيولوجية لأسد المن
}

\author{
ميرفت عبد السميع قنديل - همت ذكريا محمد مصطفى - كارم ابو زيد حسن \\ معهد بحوث وقاية النباتات - مركز البحوث الزراعية - الدقي - الجيزة - مصر
}

نم در اسة تأثير مركب من مجمو عات مانعات التغذية Chromafonozide السام و المتأخر

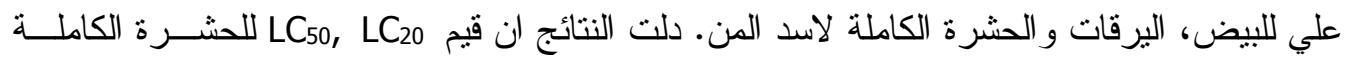

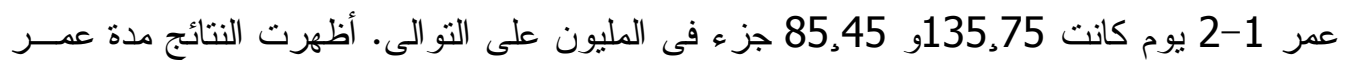

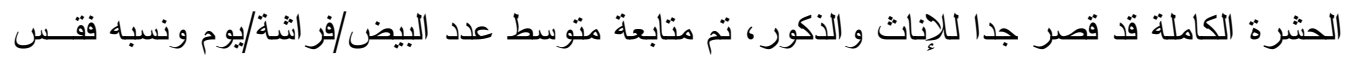

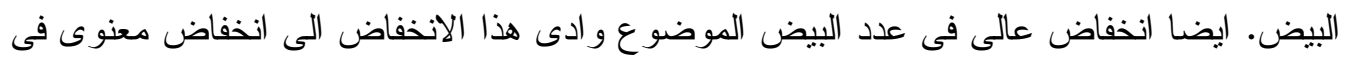
متوسط عدد البيض لكل انثى فى اليوم و \% الفقس. من ناحية اخرى البيض الناتج من معاملة الحشرة

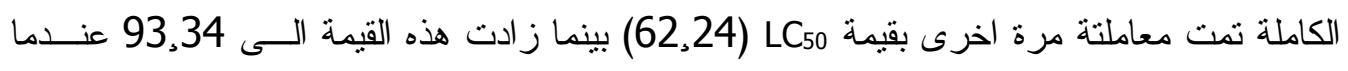

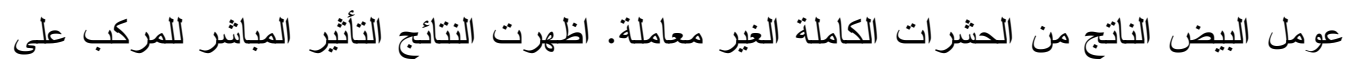

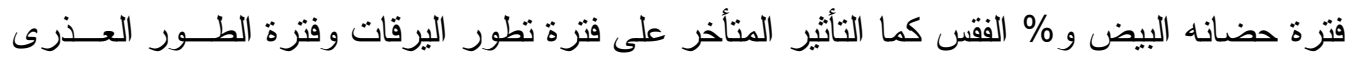
تأثرت ايضا معنويا وحدث إنخفاض فى خروج الحشرة الكاملة من كل من معاملات البيض مع زئلة فيادة

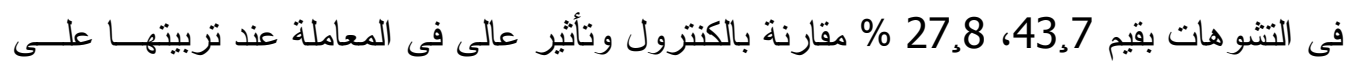

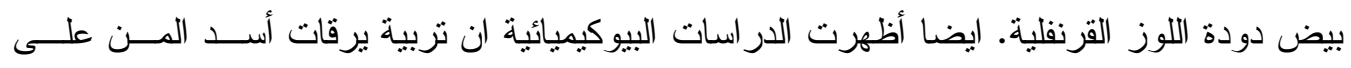

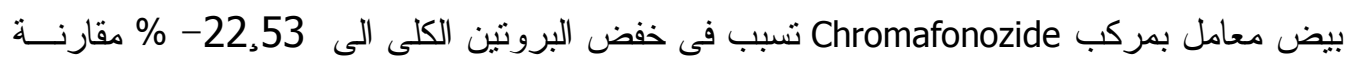

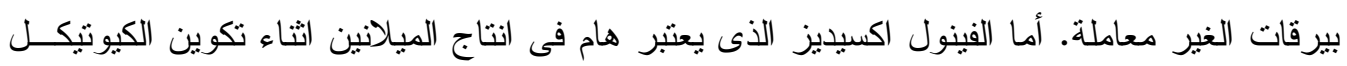

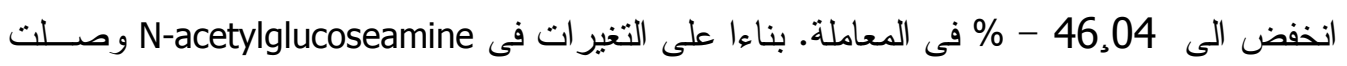

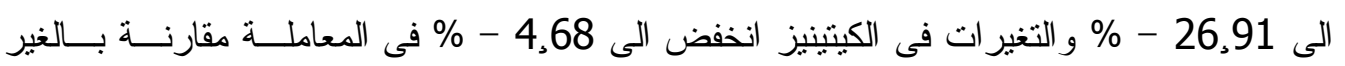
معامل. كلمات مفتاحية: كروموفينوزيد - مفترس اسد المن - دودة اللوز القرنفلية. 
